\title{
THERMOVISION AND SPECTROPHOTOMETRIC ANALYSIS OF INK VOLUME AND MATERIAL CHARACTERISTICS INFLUENCE ON COLOUR CHANGES OF HEAT TREATED PRINTED SUBSTRATES
}

\author{
Nemanja Kašiković, Dragoljub Novaković, Neda Milić, Gojko Vladić, Željko Zeljković, Mladen Stančić
}

Original scientific paper

This paper presents experimental usage of updated control methods such as thermovision and spectrophotometric analysis in graphic industry. These methods were applied to research the influence of ink volume and material characteristics on colour and heat treated printed substrates. Samples used in these experiments were printed by digital ink jet printing technique using Mimaki JV22 printing machine and J-Eco Subly Nano inks. As printing substrates, three different types of materials were used. Materials were different in respect of fabric weight and thread count, while material composition was the same for all three materials. The appropriate test card consisting of fields of CMYK colours was printed, varying the number of ink layers applied. Samples were exposed to heat treatment after printing. The heat applied was measured by thermovision camera. Spectrophotometric measurements were conducted before and after heat treatment. Based on data gathered by spectrophotometric measurements colour difference $\Delta E_{76}$ was calculated. Results showed that increasing number of layers, as well as right choice of substrates, can improve behaviour of printed product during exploitation.

Keywords: digital textile printing; heat treatment; ink layers; material characteristics

\section{Termovizijska i spektrofotometrijska analiza diferenciranog nanosa boja na specifične podloge izložene toplinskim opterećenjima}

Izvorni znanstveni članak

U radu su predstavljene primjene suvremenih metoda kontrole, kao što su termovizijska i spektrofotometrijska analiza, u grafičkoj industriji. Suvremene metode kontrole primijenjene su pri istraživanju parametara diferenciranog nanosa boje na specifične podloge izložene toplotnim opterećenjima. Uzorci koji su rabljeni za istraživanje odštampani su Ink jet postupkom na digitalnom tiskarskom stroju Mimaki JV 22 koja koristi J-Eco Subly nano boje. U procesu tiska, rabljene su tri vrste podloga, pri čemu je za sve njih sastav materijala bio isti, ali su se razlikovale prema parametrima površinske mase gustoće pletenja. Odgovarajuća test karta koja se sastojala od polja CMYK otiskana je s pet različitih nanosa boje. Ti uzorci su izloženi toplinskom djelovanju, pri čemu je polje toplinskog djelovanja mjereno termovizijskom kamerom. Uzorci su analizirani spektrofotometrijskim mjerenjima prije poslije toplinskog djelovanja te je na osnovu tih podataka određena vrijednost razlike boje $\left(\Delta E_{76}\right)$. Dobiveni rezultati su pokazali da povećanje broja nanosa boje, kao i odabir odgovarajuće podloge za štampu, može povećati eksploatacijske karakteristike otisaka.

Ključne riječi: digitalni tisak tekstila; karakteristike podloge; nanosi boje; toplotno djelovanje

\section{Introduction}

In order to achieve the best possible quality of final product, manufacturers have to use measurements and control techniques up to date, regardless of the industry type. Besides spectrophotometric print measurements and analysis which are widely spread in graphic industry, measurement methods such as thermovision are more often used today. Thermovision measurements enable control of process parameters that have influence on quality of final products especially textile products that are usually exposed to heat treatment.

When special attention is given to the part of graphical industry that deals with textile printing it can be observed that nowadays a wide range of textile materials and different printing techniques are used. Among techniques used for textile printing, digital printing is taking significant market share due to its advantages [1]. The quality of colour reproduction on textile materials is influenced by wide variety of factors, such as graphic system used for printing, ink volume, ink characteristics, substrate characteristics, etc.

During exploration printed products are exposed to variety of environmental factors such as light, heat, chemical agents, etc. [2]. Heat treatment of printed textile products is usually used during manufacturing process in order to achieve better visual effects. Heat can be applied by any heating element such as a hand held or an industrial iron. In these processes heat applied influences ink as well as textile fibres of printed material. As a consequence characteristics of printed colour are changed.

In order to achieve desired quality, changes in colour should be as small as possible. Besides standard criteria for evaluation of colour fastness such as gray-scale, instrumental spectrophotometric measurements are used to quantify changes in colour. When the top quality is a goal, manufacturers cannot rely on visual judgment as used in gray-scale method. Much more reliable is determination of colour characteristics and colour differences by means of instrumental measurements which provide numerical values for describing colour. Graphic industry has predetermined colour management standards which include such objective methods of describing colour and colour differences.

Spectrophotometer and colorimeter are instruments most often used for colour determination. Although spectrophotometers give more precise measurements of colour characteristics, colorimeters are also often used because they are more affordable. As a result of spectrophotometric measurement spectrophotometric curve is created due to emission, reflection and transmission factors. Today's spectrophotometers provide CIE standard observer settings as well as standard light sources. Information retrieved from the instrument can be translated to any stimulus colour model. Colour difference can be calculated based on colour characteristics measured by instrument, thus provide objective information of colour reproduction and any changes in 
colour during production or exploitation.

Heat can be transferred from heating element to textile material by means of conduction, convection and radiation $[3,4,5]$. In order to examine influence of heat treatment on print it is of crucial importance to gather accurate values of temperature transmitted by heating element. Measurement of temperatures is possible by usage of thermovision cameras. Although heating element gives constant temperatures, these temperatures are different across the heating surface. Thermovision cameras give precise information related to temperatures in certain areas of heating element surface.

This is possible by capturing image of infra-red radiation. Measurements gathered by thermovision camera are more accurate than other measurement methods since its non-intrusive measurement method (does not disturb the measured field of temperature) and it gives very accurate and precise measurements $[6,7]$.

Principle of measurement is based on:

- $\quad$ Temperature is measured from heating field [8];

- Appropriate software can calculate temperatures according to image captured by thermal imaging camera and it can be further analysed [9];

- Temperature value can be expressed as function of five parameters [10]:

$T_{\mathrm{ob}}=f\left(\varepsilon_{\mathrm{ob}}, T_{\mathrm{atm}}, T_{0}, \omega, d\right), \mathrm{K}$

where: $\varepsilon_{\mathrm{ob}}-$ band emissivity of investigated surface, $T_{\mathrm{atm}}$ - temperature of atmosphere, $T_{0}$ - ambient temperature, $\omega$ - relative humidity, $d$-camera to object distance.

Having in mind that all mentioned parameters are taken into consideration during temperature measurement, precision gets very high. Additional advantage of thermo visual camera is safety of the operator because it is not in direct contact with the hot object. Procedure of taking thermo vision measurements is described in literature [11].

The right choice of printing technique is crucial for production of high quality prints. In order to make the right choice one must take into consideration all the parameters from characteristics substrates, characteristics of orienting process, quality expectations and volume of print runs. Digital ink jet printing is taking considerable market share of printed textile products due to its ability to print on wide variety of materials.

One of the possibilities provided by digital ink jet printing is printing in multiple ink layers. This possibility is utilized in this experiment. As substrate for this experiment artificial polyester textile material is chosen. This material is commonly used in production of graphic products that are exposed to environmental influences and demand long exploitation periods (for example flags, billboards, sport wear etc.).

The purpose of this conducted experiment is to determine how characteristics of material and number of ink layers of printed product which are exposed to standard heating treatment will influence print quality.

\section{Materials and methods}

This research is dealing with examination of thermal treatment conducted on three specific types of textiles printed using digital ink jet printer. Spectrophotometric measurements were conducted before and after heat treatment. For all samples, colour coordinates were determined by spectrophotometer, as well as value of colour difference of treated and untreated samples.

Following the strict scientific research methodology relevant data was measured and quantified in order to describe precise influence of heat treatment on printed samples. Samples were printed on Mimaki JV22 - 160 digital ink jet printing machine using J-Eco Subly nano inks. Three different types of textile material were selected as printing substrates, chosen because of its specific characteristics such as superior straight and durability to atmospheric influences [12]. For each of the samples the following characteristics were determined: fabric weight using standard ISO 3801, thread count (ISO 7211-1) and material composition (ISO 1833). Material characteristics are shown in Tab. 1.

Table 1 Characteristics of textile materials used in the experiment

\begin{tabular}{|c|c|c|c|c|}
\hline \multirow{2}{*}{$\begin{array}{c}\text { Tested } \\
\text { samples }\end{array}$} & \multirow{2}{*}{$\begin{array}{c}\text { Material } \\
\text { composition (\%) }\end{array}$} & \multirow{2}{*}{$\begin{array}{c}\text { Fabric } \\
\text { weight } \\
\left(\mathrm{g} / \mathrm{m}^{2}\right)\end{array}$} & \multicolumn{2}{|c|}{$\begin{array}{c}\text { Thread count } \\
(\mathrm{p} / 10 \mathrm{~cm})\end{array}$} \\
\cline { 4 - 5 } & & Warp & Weft \\
\hline Material 1 & Polyester 100 \% & 110,6 & 170 & 120 \\
\hline Material 2 & Polyester 100\% & 101,5 & 160 & 100 \\
\hline Material 3 & Polyester 100 \% & 141,3 & 260 & 120 \\
\hline $\begin{array}{c}\text { Examination } \\
\text { method }\end{array}$ & ISO 1833 & ISO 3801 & \multicolumn{2}{|c|}{ ISO 7211-2 } \\
\hline
\end{tabular}

For purpose of researching heat influence treatment custom test chart was developed sized $150 \times 10 \mathrm{~cm}$. Chart consisted of four fields sized $35 \times 10 \mathrm{~cm}$; first field -100 $\%$ cyan, second field $-100 \%$ magenta, third filed -100 $\%$ yellow and fourth filed $-100 \%$ black.

Digital ink jet printing machine Mimaki JV22 - 160 provides possibility to print multiple ink layers, used in order to print test charts in five different number of ink layers. Therefore measurement and analysis included these variations in combination with thermal treatment in order to examine influence of ink volume on colour changes related to heat treatment.

One could assume that increasing ink volume will also increase durability over long period of use and exposure to heat treatment. For colorimetric measurements and reflection measuring spectrophotometer Datacolor Spectraflash SF 600® PLUS - CT was used with D65 light source, standard observer $10^{\circ}$ and aperture $16 \mathrm{~mm}$.

60 samples were analysed altogether, 20 samples of each material varying colours and number of ink layers. Exposing samples to heat treatment was conducted according to standard ISO 105-X11. Recommended temperature for this material composition is $110^{\circ} \mathrm{C}$.

In order to apply heat load on printed samples Quick Tech 45 was used. Heating element was preheated on desired temperature in order to achieve constant temperature during experiment. To achieve precise and constant thermal treatment thermovision IR camera FLIR P65 was utilized. This camera provided thermal imaging and temperature measurements of heating surface.

After thermal treatment of samples spectrophotometric measurement was conducted in order to determine influence of thermal treatment on printed samples and their colour. In order to determine statistically how 
material characteristic and number of ink layer influence the colour differences (CIE LCH colour space) caused by ironing ANOVA, tests were used.

\section{Results}

In this chapter results gathered by instrumental measurements are reported. Results are divided according to the type of measurement conducted.

\subsection{Spectrophotometric measurements after printing process}

After samples were printed, coordinates CIE $L$ (lightness), $a$ (green-red coordinate), $b$ (blue-yellow coordinate), $C$ (chroma) and $H$ (hue) colour coordinates (CIE Lab and LCH colour spaces) were determined for all printed samples. The CIE LCH colour space is similar to CIELAB, with polar coordinates of chroma $(C)$ and hue $(H)$ derived directly from the rectangular ones $-a$ and $b$ value, while lightness coordinate $\mathrm{L}$ is the same in both spaces. The reason for calculating $\mathrm{C}$ and $\mathrm{H}$ values lies in their intuitive connection with human perception of colour. Results are presented in Tab. 2, 3 and 4. In the same table colour difference between samples and sample printed with five ink layers was given. All the samples were compared to one printed with five layers because earlier research shows that five layer prints showed best light fastness [13]. Colour difference was calculated using $\Delta E_{76}$ formula. The colour difference $\Delta E_{76}$ is generally calculated as the square root of the combined squares of the chromaticity differences, $\Delta a$ and $\Delta b$, and the Lightness difference, $\Delta L$. Colour difference $\Delta E_{76}$ was chosen as recommended by [14].

Besides values of colour coordinates and colour difference, the Pearson correlation coefficient $(r)$ and the corresponding coefficient of determination $\left(r^{2}\right)$ between lightness and ink layer number and between chroma and ink layer number are shown.

Table 2 Spectrophotometer measurement results for material 1

\begin{tabular}{|c|c|c|c|c|c|c|c|c|}
\hline Sample & $L$ & $a$ & $b$ & $C$ & $h$ & $\Delta E$ & $\begin{array}{c}r\left(r^{2}\right)(L \text { and ink layer } \\
\text { number })\end{array}$ & $\begin{array}{c}r\left(r^{2}\right)(C \text { and ink layer } \\
\text { number })\end{array}$ \\
\hline $1-1 \mathrm{C}$ & 48,29 & $-7,29$ & $-31,13$ & 31,97 & 256,82 & 16,74 & \multirow{5}{*}{$\begin{array}{l}-0,99 \\
(0,98) \\
\end{array}$} & \multirow{5}{*}{$\begin{array}{l}-0,97 \\
(0,94)\end{array}$} \\
\hline $1-2 \mathrm{C}$ & 43,78 & $-6,09$ & \begin{tabular}{r|}
$-27,7$ \\
\end{tabular} & 28,36 & 257,6 & $\begin{array}{ll}11,1 \\
\end{array}$ & & \\
\hline $1-3 C$ & 39,94 & $-5,82$ & $-25,95$ & 26,6 & 257,36 & 6,9 & & \\
\hline $1-4 C$ & 36,15 & $-5,29$ & $-24,75$ & 25,31 & 257,94 & 2,89 & & \\
\hline $1-5 C$ & 33,5 & $-4,72$ & $-23,74$ & 24,2 & 258,77 & 1 & & \\
\hline $1-1 \mathrm{M}$ & 46,74 & 48,71 & 0,88 & 48,72 & 1,03 & 16,38 & \multirow{5}{*}{$\begin{array}{r}-0,98 \\
(0,96)\end{array}$} & \multirow{5}{*}{$\begin{array}{l}-0,98 \\
(0,96)\end{array}$} \\
\hline $1-2 \mathrm{M}$ & 41,34 & 44,94 & 2,95 & 45,03 & 3,76 & 9,56 & & \\
\hline $1-3 \mathrm{M}$ & 39,24 & 41,96 & 2,59 & 42,04 & 3,53 & 6,2 & & \\
\hline $1-4 \mathrm{M}$ & 36,54 & 40,27 & 3,45 & 40,42 & 4,9 & 2,91 & & \\
\hline $1-5 \mathrm{M}$ & 34,37 & 38,54 & \begin{tabular}{|l|}
4,33 \\
\end{tabular} & 38,78 & 6,41 & 1 & & \\
\hline $1-1 Y$ & 78,28 & $-2,73$ & 65,72 & 65,77 & 92,38 & 16,57 & \multirow{5}{*}{$\begin{array}{l}-0,99 \\
(0,98)\end{array}$} & \multirow{5}{*}{$\begin{array}{r}0,94 \\
(0,88)\end{array}$} \\
\hline $1-2 \mathrm{Y}$ & 74,64 & 1,78 & 68,71 & \begin{tabular}{|l|}
68,73 \\
\end{tabular} & 88,52 & 10,12 & & \\
\hline $1-3 \mathrm{Y}$ & 72,02 & 4,39 & 70,92 & 71,05 & 86,46 & 6,03 & & \\
\hline $1-4 \mathrm{Y}$ & 69,81 & 6,78 & 71,71 & 72,03 & 84,6 & 2,73 & & \\
\hline $1-5 \mathrm{Y}$ & 68,03 & 8,84 & 71,67 & 72,22 & 82,97 & 1 & & \\
\hline $1-1 \mathrm{~K}$ & 36,04 & $\begin{array}{l}-0,33 \\
\end{array}$ & $-1,18$ & 1,23 & 254,56 & 13,89 & \multirow{5}{*}{$\begin{array}{l}-0,96 \\
(0,92) \\
\end{array}$} & \multirow{5}{*}{$\begin{array}{l}-0,91 \\
(0,83) \\
\end{array}$} \\
\hline $1-2 \mathrm{~K}$ & 30,01 & $-0,65$ & $-0,91$ & 1,12 & 234,55 & 7,85 & & \\
\hline $1-3 K$ & 25,68 & $-0,4$ & $-1,02$ & 1,1 & 248,63 & 3,52 & & \\
\hline $1-4 \mathrm{~K}$ & 23,35 & $-0,58$ & $-0,95$ & 1,11 & 238,68 & 1,19 & & \\
\hline $1-5 \mathrm{~K}$ & 22,16 & $-0,51$ & $-0,88$ & 1,02 & 239,54 & 1 & & \\
\hline
\end{tabular}

Table 3 Spectrophotometer measurement results for material 2

\begin{tabular}{|c|c|c|c|c|c|c|c|c|}
\hline Sample & $L$ & $a$ & $b$ & C & $h$ & $\Delta \mathrm{E}$ & $\begin{array}{c}r\left(r^{2}\right)(L \text { and ink layer } \\
\text { number })\end{array}$ & $\begin{array}{c}r\left(r^{2}\right)(C \text { and ink layer } \\
\text { number })\end{array}$ \\
\hline $2-1 \mathrm{C}$ & 44,21 & $-4,32$ & $-31,74$ & 32,03 & 262,25 & 18,99 & \multirow{5}{*}{$\begin{array}{l}-0,97 \\
(0,94)\end{array}$} & \multirow{5}{*}{$\begin{array}{l}-0,95 \\
(0,90)\end{array}$} \\
\hline $2-2 C$ & 37,11 & $-2,44$ & $-27,27$ & 27,38 & 264,88 & 10,4 & & \\
\hline $2-3 C$ & 34,42 & $-0,02$ & $-24,02$ & 24,02 & 269,95 & 6,3 & & \\
\hline $2-4 C$ & 30,73 & $-1,23$ & $-23,17$ & 23,2 & 266,96 & 2,74 & & \\
\hline $2-5 C$ & 28,62 & $-0,46$ & $-21,6$ & 21,6 & 268,79 & 1 & & \\
\hline $2-1 \mathrm{M}$ & 43,07 & 49,59 & 1,55 & 49,62 & 1,79 & 18,78 & \multirow{5}{*}{$\begin{array}{l}-0,95 \\
(0,90)\end{array}$} & \multirow{5}{*}{$\begin{array}{l}-0,96 \\
(0,92)\end{array}$} \\
\hline $2-2 \mathrm{M}$ & 36,49 & 42,8 & 3,12 & 42,92 & 4,17 & 9,29 & & \\
\hline $2-3 \mathrm{M}$ & 32,81 & 38,87 & 5,51 & 39,26 & 8,06 & 4,55 & & \\
\hline $2-4 \mathrm{M}$ & 32,79 & 38,66 & 5,12 & 39 & 7,55 & 4,21 & & \\
\hline $2-5 \mathrm{M}$ & 29 & 32,36 & 5,28 & 32,79 & 9,26 & 1 & & \\
\hline $2-1 Y$ & 77,17 & 4,82 & 75,02 & 75,18 & 86,32 & 20,86 & \multirow{5}{*}{$\begin{array}{l}-0,99 \\
(0,98) \\
\end{array}$} & \multirow{5}{*}{$\begin{array}{l}-0,96 \\
(0,92)\end{array}$} \\
\hline $2-2 Y$ & 71,77 & 4,82 & 75,02 & 75,18 & 86,32 & 15,02 & & \\
\hline $2-3 Y$ & 67,91 & 6,93 & 72,02 & 72,36 & 84,5 & 10,03 & & \\
\hline $2-4 \mathrm{Y}$ & 64,85 & 8,49 & 68,91 & 69,43 & 82,98 & 5,77 & & \\
\hline $2-5 \mathrm{Y}$ & 62,31 & 8,95 & 65,05 & 65,66 & 82,17 & 1 & & \\
\hline $2-1 K$ & 27,28 & $-0,3$ & $-0,14$ & $\begin{array}{l}0,33 \\
\end{array}$ & 205,02 & 6,4 & \multirow{5}{*}{$\begin{array}{l}-0,93 \\
(0,86)\end{array}$} & \multirow{5}{*}{$\begin{array}{l}-0,77 \\
(0,59)\end{array}$} \\
\hline $2-2 K$ & 23,81 & $-0,43$ & $-0,14$ & 0,45 & 198,29 & 2,96 & & \\
\hline $2-3 K$ & 22,23 & $-0,18$ & $-0,19$ & 0,26 & 227 & 1,36 & & \\
\hline $2-4 \mathrm{~K}$ & 21,52 & $-0,1$ & $-0,09$ & 0,14 & 222,64 & 0,66 & & \\
\hline $2-5 \mathrm{~K}$ & 20,97 & 0,07 & $-0,18$ & 0,19 & 293,04 & 1 & & \\
\hline
\end{tabular}


Table 4 Spectrophotometer measurement results for material 3

\begin{tabular}{|c|c|c|c|c|c|c|c|c|}
\hline Sample & $L$ & $a$ & $b$ & $C$ & $h$ & $\Delta E$ & $\begin{array}{c}\mathrm{r}\left(r^{2}\right)(L \text { and ink layer } \\
\text { number })\end{array}$ & $\begin{array}{c}r\left(r^{2}\right)(C \text { and ink layer } \\
\text { number })\end{array}$ \\
\hline $3-1 \mathrm{C}$ & 52,3 & $-0,53$ & $-32,08$ & 32,09 & 269,06 & 17,98 & \multirow{5}{*}{$\begin{array}{l}-0,93 \\
(0,86)\end{array}$} & \multirow{5}{*}{$\begin{array}{l}-0,99 \\
(0,98)\end{array}$} \\
\hline $3-2 \mathrm{C}$ & 42,67 & $-0,31$ & $-31,27$ & 31,27 & 269,43 & 8,67 & & \\
\hline $3-3 C$ & 38,89 & 0,73 & $-30,16$ & 30,17 & 271,38 & 4,65 & & \\
\hline $3-4 C$ & 36,69 & 2,45 & $-28,95$ & 29,05 & 274,84 & 2,14 & & \\
\hline $3-5 \mathrm{C}$ & 34,95 & 1,75 & $-27,91$ & 27,97 & 273,59 & 1 & & \\
\hline $3-1 \mathrm{M}$ & 51,34 & 38,48 & $-8,58$ & 39,43 & 352,19 & 21,12 & \multirow{5}{*}{$\begin{array}{l}-0,90 \\
(0,81)\end{array}$} & \multirow{5}{*}{$\begin{array}{l}-0,87 \\
(0,76) \\
\end{array}$} \\
\hline $3-2 \mathrm{M}$ & 39,15 & 41,25 & $-3,06$ & 41,36 & 355,75 & 11,65 & & \\
\hline $3-3 M$ & 36,62 & 33,33 & $-4,57$ & 33,64 & 352,19 & 5,09 & & \\
\hline $3-4 \mathrm{M}$ & 34,49 & 31,06 & $-4,06$ & 31,33 & 352,56 & 2,91 & & \\
\hline $3-5 \mathrm{M}$ & 32,28 & 31,87 & $-2,35$ & 31,96 & 355,78 & I & & \\
\hline $3-1 Y$ & 79,74 & $-3,25$ & 68,35 & 68,42 & 92,72 & 16,53 & \multirow{5}{*}{$\begin{array}{l}-0,99 \\
(0,98)\end{array}$} & \multirow{5}{*}{$\begin{array}{l}-0,83 \\
(0,69)\end{array}$} \\
\hline $3-2 Y$ & 75,14 & 2,06 & 68,87 & 68,9 & 88,29 & 10,02 & & \\
\hline $3-3 Y$ & 72,56 & 3,81 & 68,68 & 68,78 & 86,83 & 7,13 & & \\
\hline $3-4 Y$ & 69,69 & 6,53 & 66,88 & 67,2 & 84,42 & 2,88 & & \\
\hline $3-5 Y$ & 67,68 & 7,59 & 65,12 & 65,56 & 83,35 & 1 & & \\
\hline $3-1 K$ & 35,17 & 3,42 & 0,85 & 3,52 & 13,89 & 12,86 & \multirow{5}{*}{$\begin{array}{l}-0,90 \\
(0,81)\end{array}$} & \multirow{5}{*}{$\begin{array}{l}-0,72 \\
(0,52)\end{array}$} \\
\hline $3-2 \mathrm{~K}$ & 26,84 & 1,64 & $-0,3$ & 1,67 & 349,55 & 4,33 & & \\
\hline $3-3 K$ & 26,03 & 1,58 & $-0,27$ & 1,6 & 350,32 & 3,53 & & \\
\hline $3-4 \mathrm{~K}$ & 24,15 & 1,53 & $-0,17$ & 1,54 & 353,8 & 1,67 & & \\
\hline $3-5 \mathrm{~K}$ & 22,52 & 1,55 & $-0,51$ & 1,63 & 341,99 & 1 & & \\
\hline
\end{tabular}

while the letter represents colour that the sample was printed in.

\subsection{Thermovision measurements}

Thermovision camera was used for measurement of heating element temperature. According to standard ISO 105-X11 temperature of $110{ }^{\circ} \mathrm{C}$ is recommended for material composition used in this experiment. Surface of heating element was cleaned and prepared for measurement. The whole process of heat treatment was filmed with a thermovision camera. Special attention was given in order to minimize or completely eliminate temperature variations. Fig. 1 represents characteristic values of temperatures used in this experiment.

As it can be seen from Fig. 1 there are some differences in temperature of the heating element surface. In order to eliminate possibility of variation in thermal load applied, all the samples were positioned in the same spot so they can be in contact in the centre of the heating element where temperature was constant.

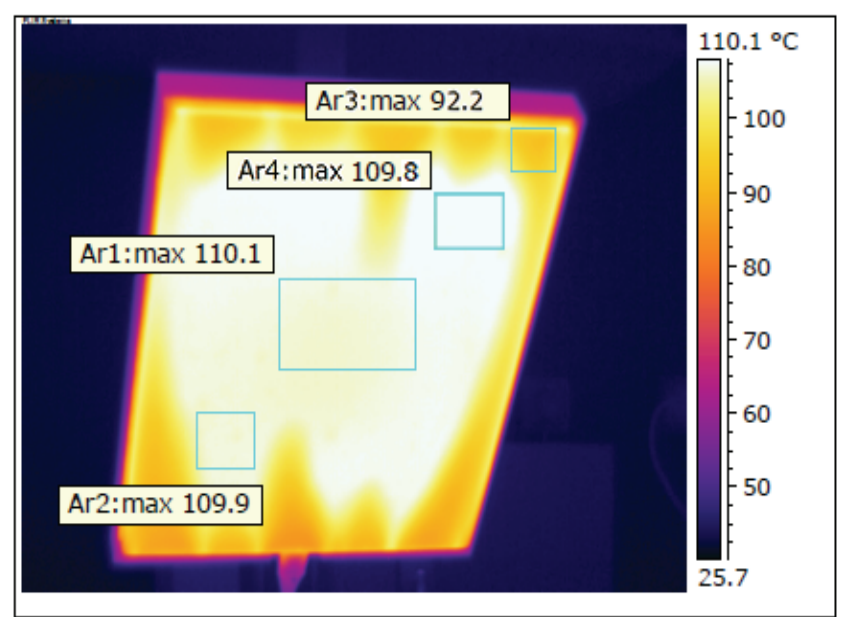

Figure 1 Thermovision image of heating element

\subsection{Spectrophotometric measurements after thermal load}

After thermal treatment of printed samples spectrophotometric measurements were done in order to determine influence of thermal treatment on the printed samples. Earlier research with similar topic [15] showed that the number of ink layers does not influence amount of changes caused by thermal treatment. These researches based their conclusion on visual judgment, grayscale method while this research presented instrumental measurements. Results of these measurements, values of $\Delta L, \Delta a, \Delta b, \Delta C$ and $\Delta h$ are shown in Tabs. 5, 6 and 7 .

Measured values of colour coordinates before and after heat treatment for all variations of ink layers are presented in 3-dimensional colour space, Figs. 2, 3 and 4. Summary of colour differences grouped by colour is shown in Fig. 5.

Table 5 Differences of colour coordinates before and after thermal load for material 1 .

\begin{tabular}{|c|c|c|c|c|c|}
\hline Sample & $\Delta L$ & $\Delta a$ & $\Delta b$ & $\Delta C$ & $\Delta h$ \\
\hline $1-1 \mathrm{C}$ & 2,39 & $-0,33$ & $-1,09$ & 1,13 & $-0,36$ \\
\hline $1-2 \mathrm{C}$ & 0,23 & $-0,25$ & $-2,26$ & 2,27 & 0,37 \\
\hline $1-3 C$ & $-1,53$ & 0,84 & $-0,99$ & 0,79 & 2,45 \\
\hline $1-4 \mathrm{C}$ & $-1,24$ & 0,58 & 0,42 & $-0,53$ & 5,71 \\
\hline $1-5 \mathrm{C}$ & $-0,1$ & $-0,58$ & $-0,24$ & 0,37 & $-1,07$ \\
\hline $1-1 \mathrm{M}$ & 1,27 & 3,88 & $-0,56$ & 3,82 & $-1,1$ \\
\hline $1-2 \mathrm{M}$ & 1,44 & 2,75 & $-0,09$ & 2,74 & $-0,27$ \\
\hline $1-3 \mathrm{M}$ & $-1,47$ & $-0,67$ & $-0,16$ & $-0,69$ & $-0,15$ \\
\hline $1-4 \mathrm{M}$ & 0,9 & 0,78 & $-0,21$ & 0,77 & $-0,28$ \\
\hline $1-5 \mathrm{M}$ & 0,73 & $-0,42$ & $-0,28$ & $-0,43$ & $-0,27$ \\
\hline $1-1 Y$ & 1,08 & $-1,12$ & $-0,13$ & $-0,26$ & 1,09 \\
\hline $1-2 Y$ & 0,03 & $-1,13$ & $-0,94$ & $-1,03$ & 1,12 \\
\hline $1-3 Y$ & 0,92 & $-0,63$ & $-0,49$ & $-0,57$ & 0,54 \\
\hline $1-4 Y$ & 1,03 & 0,25 & $-0,3$ & $-0,28$ & $-0,3$ \\
\hline $1-5 Y$ & 0,28 & $-0,41$ & 0,65 & 0,59 & 0,48 \\
\hline $1-1 \mathrm{~K}$ & 0,95 & 0,48 & $-0,58$ & 0,71 & - \\
\hline $1-2 \mathrm{~K}$ & 1,16 & 0,24 & $-0,2$ & 0,31 & - \\
\hline $1-3 \mathrm{~K}$ & 0,39 & 0,75 & $-0,37$ & 0,83 & - \\
\hline $1-4 \mathrm{~K}$ & $-0,63$ & $-0,27$ & $-0,08$ & $-0,18$ & - \\
\hline $1-5 \mathrm{~K}$ & $-0,27$ & 0,07 & 0,58 & $-0,28$ & - \\
\hline
\end{tabular}

Note: Labels in the Sample column are structured so that the first number represents textile material; the second number represents number of ink layers while the letter represents colour that the sample was printed in. The value of hue change $\Delta h$ was not calculated for black colour because of its achromacy. 
Table 6 Differences of colour coordinates before and after thermal load for material 2

\begin{tabular}{|c|c|c|c|c|c|}
\hline Samnle & $\Lambda L$ & $\Delta a$ & $\Delta h$ & $\Delta C$ & $\Delta h$ \\
\hline $2-1 \mathrm{C}$ & -0.7 & $-1,28$ & $-2,52$ & 2,64 & $-3,13$ \\
\hline $2-2 \mathrm{C}$ & 0,87 & $-0,92$ & $-0,93$ & 1,06 & $-2,03$ \\
\hline $2-3 C$ & 0,92 & $-0,45$ & $-1,19$ & 1,22 & $-1,19$ \\
\hline $2-4 C$ & 0,65 & 0,79 & 1,15 & $-1,26$ & 1,39 \\
\hline $2-5 \mathrm{C}$ & 1 & 0,12 & 0,71 & $-0,72$ & 0,1 \\
\hline $2-1 M$ & 0,46 & 2,8 & 1,36 & 2,93 & 1,24 \\
\hline $2-2 \mathrm{M}$ & 1,15 & 1,98 & 0,67 & 2,04 & 0,63 \\
\hline $2-3 \mathrm{M}$ & 1,51 & 1,67 & 0,19 & 1,68 & 0,02 \\
\hline $2-4 \mathrm{M}$ & 0,1 & 1,29 & 0,47 & 1,33 & 0,38 \\
\hline $2-5 M$ & 0,18 & $-1,15$ & $-0,63$ & $-1,21$ & $-0,65$ \\
\hline $2-1 Y$ & $-0,19$ & 0,25 & $-1,63$ & $-1,6$ & $-0,36$ \\
\hline $2-2 Y$ & $-0,36$ & 0,24 & 0,97 & 0,98 & $-0,18$ \\
\hline $2-3 Y$ & 0,15 & $-0,11$ & 0,91 & 0,89 & 0,26 \\
\hline $2-4 Y$ & 0,64 & $-0,61$ & $-0,15$ & $-0,23$ & 0,57 \\
\hline $2-5 Y$ & 0,12 & $-0,26$ & 0,06 & 0,03 & 0,25 \\
\hline $2-1 \mathrm{~K}$ & $-1,36$ & $-1,32$ & 0,49 & $-1,41$ & - \\
\hline $2-2 \mathrm{~K}$ & 0,07 & $-1,08$ & 0,26 & $-1,1$ & - \\
\hline $2-3 K$ & $-0,03$ & $-0,66$ & 0,35 & $-0,72$ & - \\
\hline $2-4 K$ & $-0,33$ & $-0,5$ & 0,27 & $-0,56$ & - \\
\hline $2-5 \mathrm{~K}$ & $-0,41$ & 0,15 & 0,42 & 0 & - \\
\hline
\end{tabular}

Note: Labels in the Sample column are structured so that the first number represents textile material; the second number represents number of ink layers while the letter represents colour that the sample was printed in. The value of hue change $\Delta h$ was not calculated for black colour because of its achromacy.
Table 7 Differences of colour coordinates before and after thermal load for material 3

\begin{tabular}{|c|c|c|c|c|c|}
\hline Sample & $\Delta L$ & $\Delta a$ & $\Delta b$ & $\Delta C$ & $\Delta h$ \\
\hline $3-1 \mathrm{C}$ & $-0,3$ & $-4,28$ & $-7,52$ & 7,98 & $-7,32$ \\
\hline $3-2 \mathrm{C}$ & 1,5 & $-1,72$ & $-7,46$ & 7,6 & $-2,27$ \\
\hline $3-3 \mathrm{C}$ & $-1,03$ & $-3,83$ & $-5,36$ & 5,97 & $-6,14$ \\
\hline $3-4 \mathrm{C}$ & $-1,09$ & $-4,06$ & $-3,71$ & 4,45 & $-7,26$ \\
\hline $3-5 \mathrm{C}$ & $-0,42$ & $-2,85$ & $-3,47$ & 3,81 & $-5,97$ \\
\hline $3-1 \mathrm{M}$ & 2,06 & 13,26 & 0,73 & 13,26 & 0,78 \\
\hline $3-2 \mathrm{M}$ & $-0,18$ & 11,16 & 3,18 & 11,37 & 3,27 \\
\hline $3-3 \mathrm{M}$ & $-0,08$ & 10,17 & 2,51 & 10,32 & 2,56 \\
\hline $3-4 \mathrm{M}$ & $-3,65$ & 7,66 & 3,23 & 7,8 & 4 \\
\hline $3-5 \mathrm{M}$ & $-0,93$ & 4,58 & 2,34 & 4,68 & 2,98 \\
\hline $3-1 Y$ & $-1,97$ & $-1,93$ & 2,24 & 2,12 & 2,1 \\
\hline $3-2 \mathrm{Y}$ & $-0,36$ & $-0,79$ & 3,29 & 3,18 & 1,14 \\
\hline $3-3 Y$ & 0,68 & $-0,2$ & 2,14 & 2,11 & 0,38 \\
\hline $3-4 Y$ & $-0,24$ & 0,87 & 1,93 & 1,96 & $-0,86$ \\
\hline $3-5 Y$ & $-0,18$ & 0,44 & 0,89 & 0,93 & $-0,33$ \\
\hline $3-1 \mathrm{~K}$ & $-4,43$ & 0,44 & $-2,89$ & 0,3 & - \\
\hline $3-2 \mathrm{~K}$ & $-3,88$ & $-1,02$ & $-1,93$ & $-1,16$ & - \\
\hline $3-3 K$ & $-3,9$ & $-0,33$ & $-1,86$ & $-0,54$ & - \\
\hline $3-4 \mathrm{~K}$ & $-2,88$ & $-1,63$ & $-0,93$ & $-1,79$ & - \\
\hline $3-5 \mathrm{~K}$ & 2,52 & 0,42 & $-0,35$ & 0,3 & \\
\hline
\end{tabular}

Note: Labels in the Sample column are structured so that the first number represents textile material; the second number represents number of ink layers while the letter represents colour that the sample was printed in. The value of hue change $\Delta h$ was not calculated for black colour because of its achromacy.
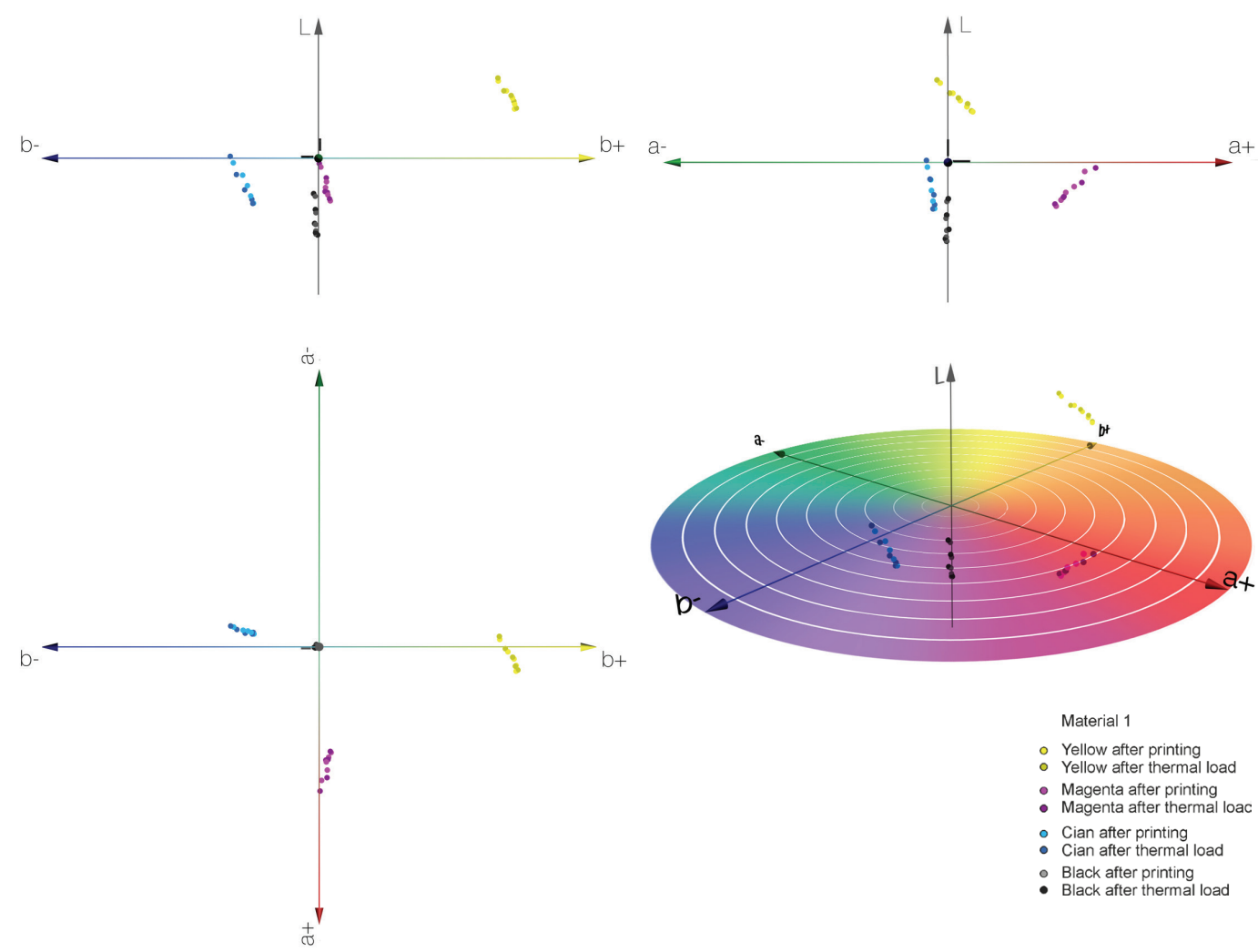

Material 1

- Yellow after printing - Yellow after thermal load - Magenta after printing - Magenta after thermal loa - Cian after printing

- Black after printing

- Black after thermal load

Figure 2 Coordinates of sample colours before and after thermal treatment of all colour printed on material 1 

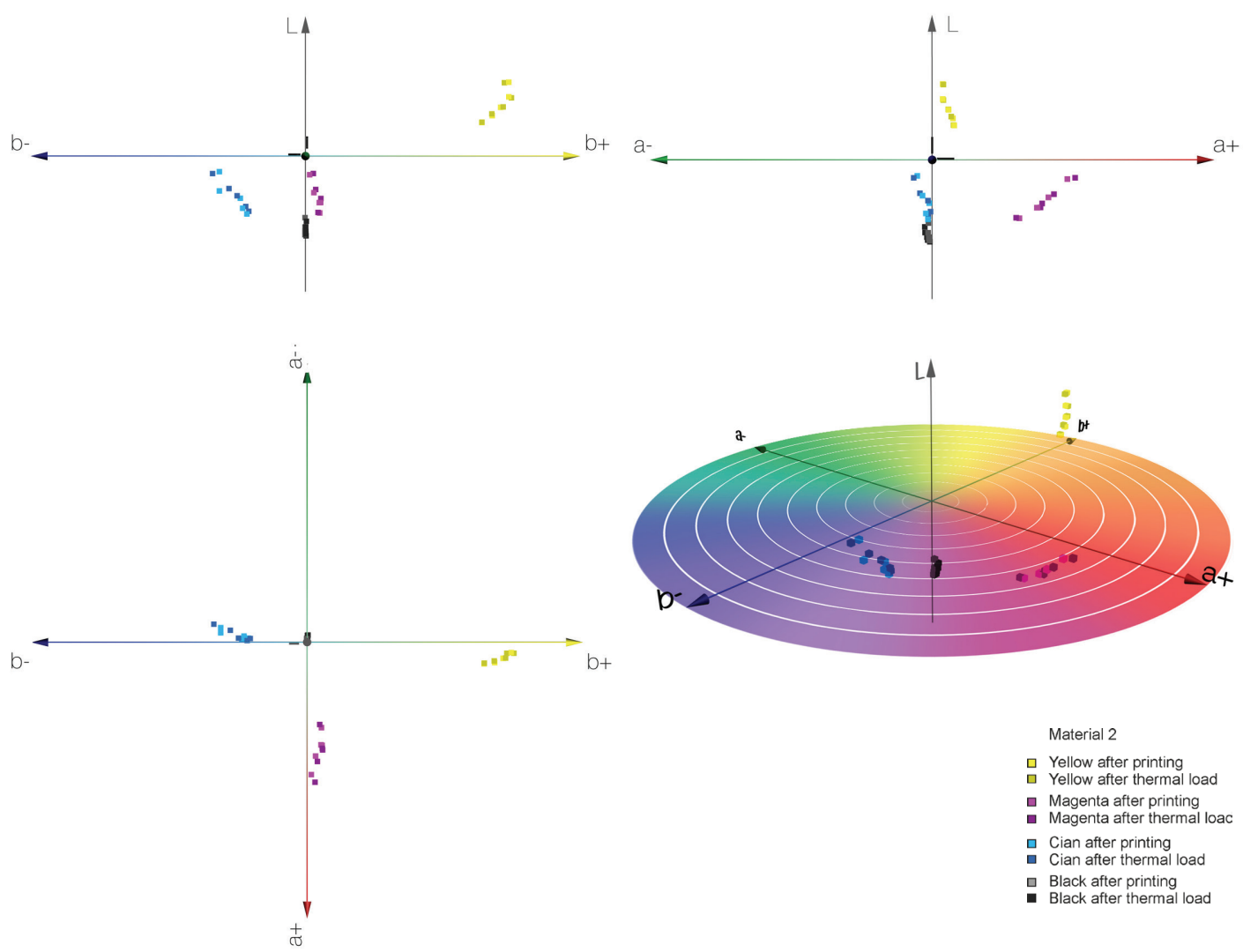

Figure 3 Coordinates of sample colours before and after thermal treatment of all colour printed on material 2
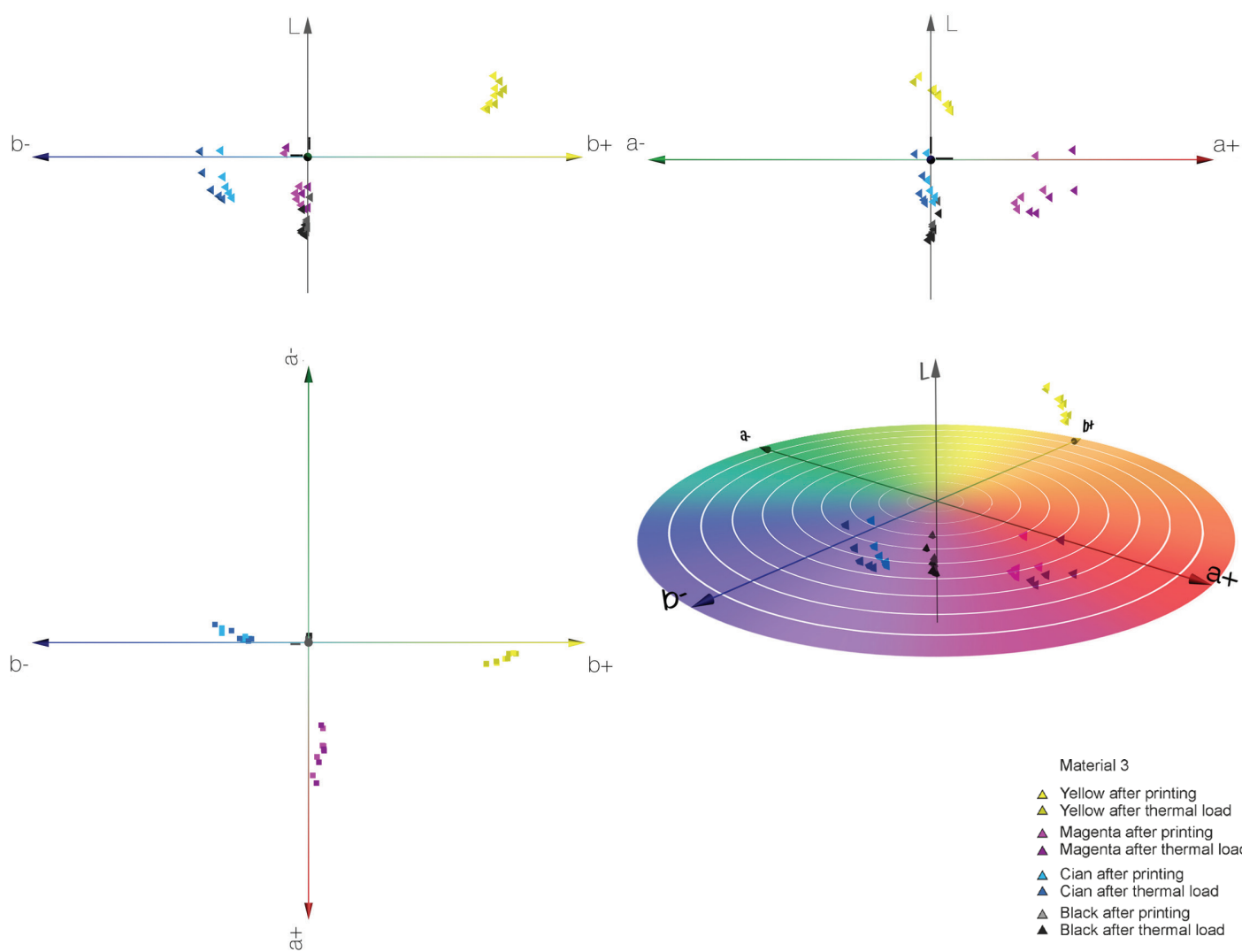

Figure 4 Coordinates of sample colours before and after thermal treatment of all colour printed on material 3 


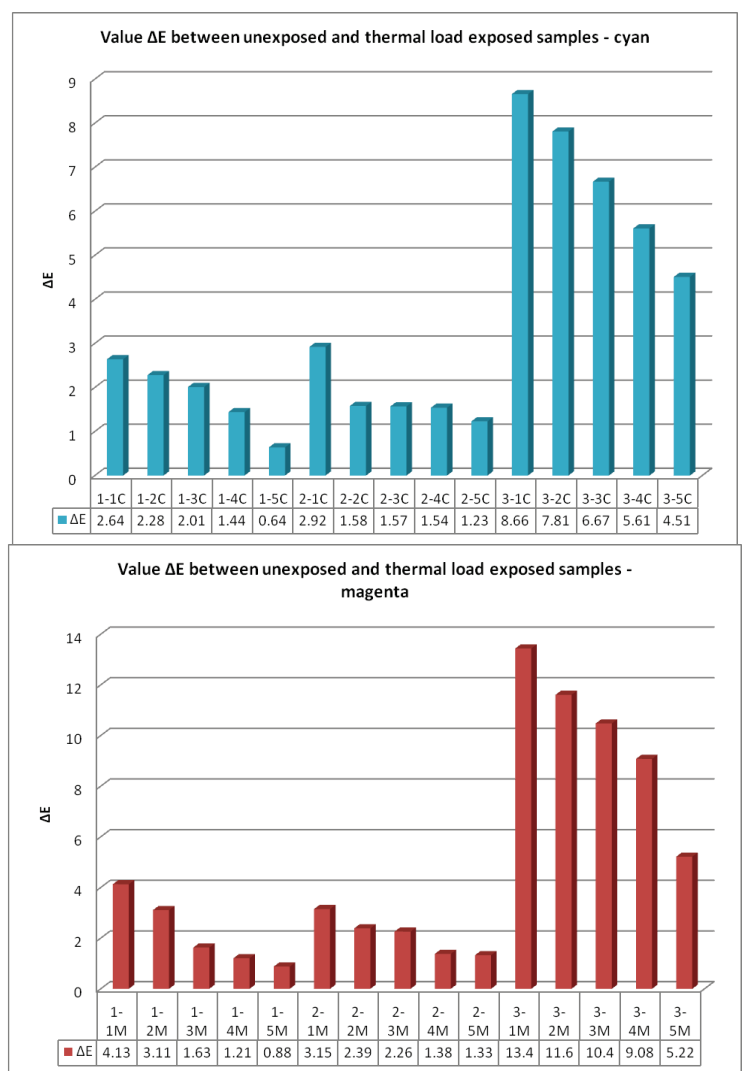

Figure 5 Value $\Delta \mathrm{E}$ between unexposed and thermal load exposed samples - all textiles printed by: a) cyan, b) magenta, c) yellow, d) black colour

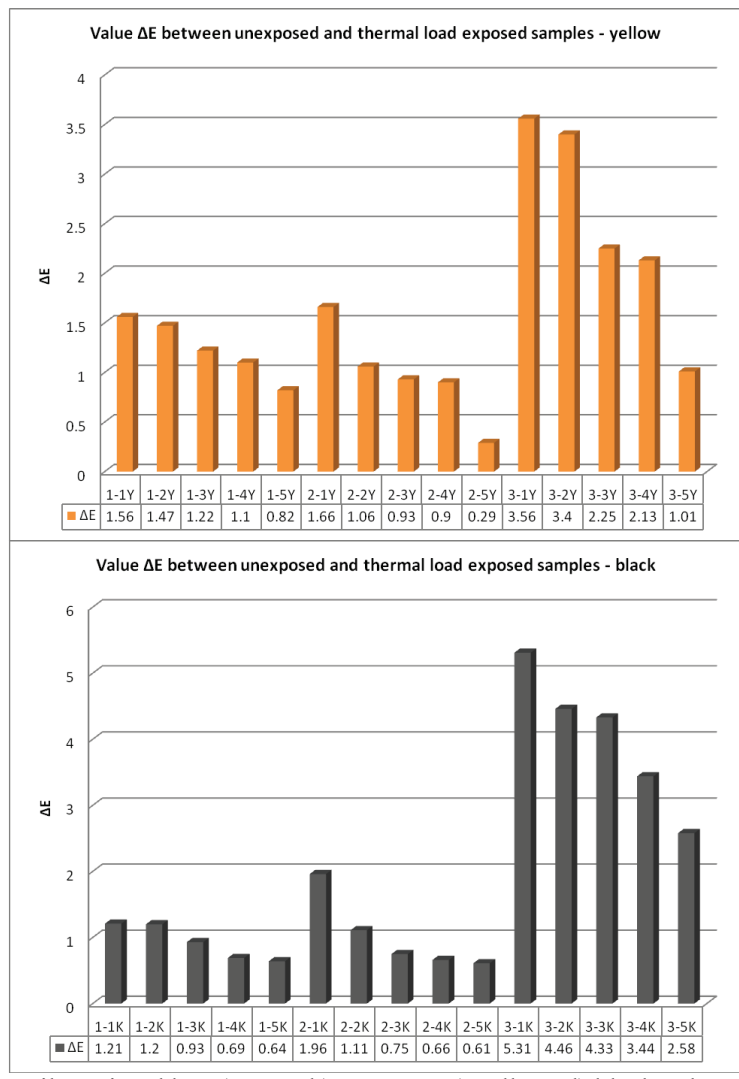

$(M=5,78, S D=3,40)$ and other two - material $1(M=1,54$, $S D=0,90)$ and material $2(M=1,46, S D=0,76)$, while material 1 and 2 did not differ significantly from each other.

After discovering the main effect of the number of ink layers on colour change, $F(4 ; 55)=2,691, p=0,043$ with partial eta squared of 0,193 (large effect size), posthoc tests showed that there was significant difference between samples with one $(M=4,18, S D=3,56)$ and with five ink layers $(M=1,65, S D=1,62)$, while the group of samples with two $(M=3,45, S D=3,2)$, three $(M=2,92$, $S D=2,92)$ and four layers $(M=2,43, S D=2,52)$ did not differ one from another and did not differ from samples with one and with five ink layers.

Tab. 8 presents colour difference grouped by influence factors: textile and number of ink layers, and Fig. 6 represents graphs of grouped colour difference.

Table 8 Differences of colour coordinates before and after thermal load (grouped by influence factor)

\begin{tabular}{|c|c|c|c|c|}
\hline \multicolumn{2}{|c|}{ Factor } & Number & Mean value & $\begin{array}{c}\text { Standard } \\
\text { deviation }\end{array}$ \\
\hline \multirow{3}{*}{ material } & $1^{\text {st }}$ & 20 & 1,5396 & 0,90130 \\
\cline { 2 - 5 } & $2^{\text {nd }}$ & 20 & 1,4619 & 0,75974 \\
\cline { 2 - 5 } & $3^{\text {rd }}$ & 20 & 5,7764 & 3,39947 \\
\hline \multirow{4}{*}{$\begin{array}{c}\text { Ink } \\
\text { layer }\end{array}$} & 1 & 12 & 4,1813 & 3,56022 \\
\cline { 2 - 5 } & 2 & 12 & 3,4547 & 3,20130 \\
\cline { 2 - 5 } & 3 & 12 & 2,9173 & 2,92195 \\
\cline { 2 - 5 } & 4 & 12 & 2,4297 & 2,52412 \\
\hline
\end{tabular}
layer and material type) produce the same colour difference, on average.

After discovering main effect of the material type on colour change, $F(2 ; 57)=29,256, p=0,000$ with partial eta squared of 0,565 (large effect size), post-hoc tests showed that statistical difference existed between material 3 

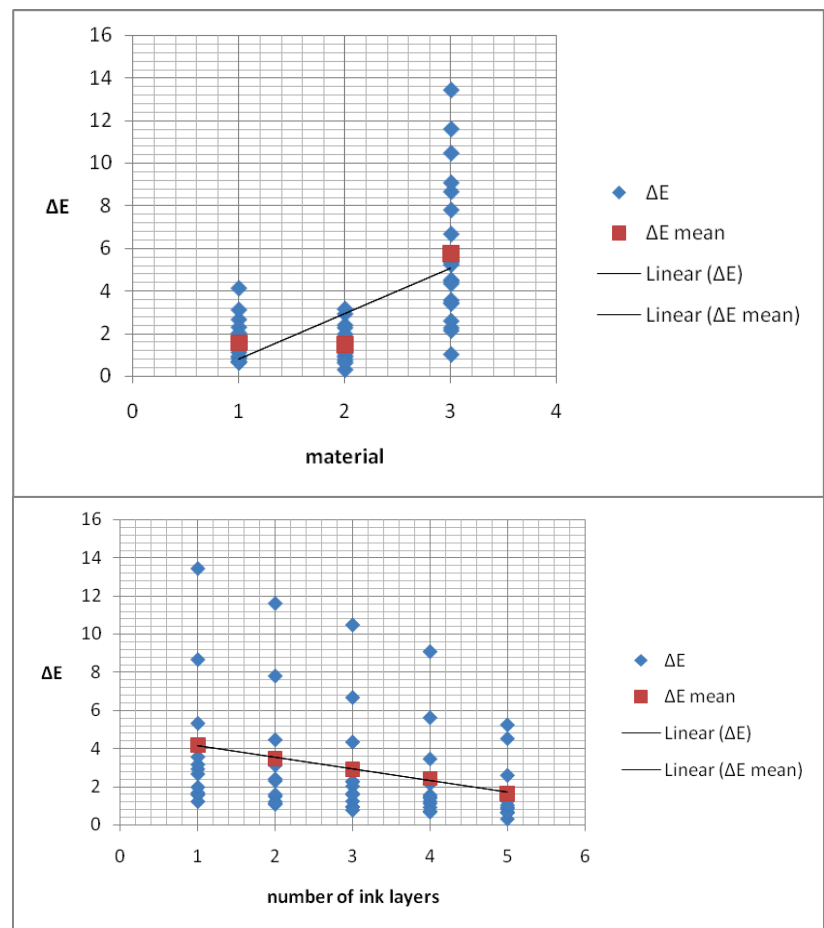

Figure 6 Colour difference graphs grouped by factors: a) material, b) number of ink layers

\section{Discussion}

Results presented in Tab. 2 show that increasing number of ink layers during print leads to decreasing of lightness and saturation at all four process colours, while hue changes are not so noticeable. Changes of lightness and saturation have linear tendency with a high value of correlation coefficient. Therefore, colour difference value will rise with change of ink layer number.

The lowest values of $\Delta E$ were calculated for black colour for all materials, while samples printed by cyan, magenta and yellow showed higher values of $\Delta E$, similar across all materials. This can be explained with the achromatic nature of black colour where change of ink layer number influences only the lightness value, while chromatic coordinates of colour (chroma and hue or $a$ and $b$ value) remain the same. Lightness change of black samples caused by adding ink layers is in the range of changes of other three colours.

Colour difference values where mostly greater than 5 , $\Delta E>5$, except in comparison to samples printed with four and five ink layers. Based on linear tendency of lightness and saturation changes it can be assumed that further increase in number of ink layer number will increase value $\Delta E$ also.

Using thermovision temperature measurements constant level of heating element surface was insured, which is shown in Fig. 1. Constant temperatures have great significance in assuring the same experimental conditions for all samples.

Results obtained by spectrophotometric measurement showed that increasing number of ink layers has significant influence on heat treatment fastness. Increasing number of ink layers thus increases ink volume results in prints and gets more resistant to heat treatment. This was observed for all colour and all materials used in this experiment.
Material 3 which has the greatest thread count and fabric weight showed greatest changes after heat treatment while material 2 that has the lowest thread count and fabric weight showed lowest values of colour difference. Increase of materials thread count results in increasing colour differences. These results can be explained by the fact that during printing, ink penetrates materials with lower thread count. Smaller amount of ink is left on the surface of the material where it is directly exposed to temperature of the heating element.

\section{Conclusion}

This research showed that changes of printed textile materials are caused by thermal treatment. This was confirmed by spectrophotometric measurement which was used to quantify colour differences before and after heat treatment. By increasing number of ink layers, value of colour difference was smaller therefore the fact of increased number of ink layers could be characterized as positive. The choice of materials that are used as printing substrates is also influential factor on quality of prints and exploitation characteristics of products. Samples made of material 3 showed the worst exploitation characteristics. Material 3 had the greatest thread count and fabric weight. Values for colour differences before and after heat treatment for material 1 and 2 are similar, which can be explained by similarities in thread count and fabric weight of these materials.

\section{Acknowledgements}

This work was supported by the Serbian Ministry of Science and Technological Development, Grant No.: 35027 "The development of software model for improvement of knowledge and production in graphic arts industry"

\section{References}

[1] Kašiković, N.; Novaković, D.; Vladić, G.; Avramović D. Influence of ink layers on the colour fastness to rubbing of printed textile materials. // Tekstilna industrija. 60, 2(2012), pp. 28-32.

[2] Kašiković, N.; Novaković, D.; Vladić, G.; Klančnik, M. Influence of heat treatment on characteristics of Inkjet print on textile material. // Journal of Graphic Engineering and Design. 2, 1(2011), pp. 24-30.

[3] Mao, N.; Russell, S. J. The Thermal Insulation Properties of Spacer Fabrics with a Mechanically Integrated Wool Fibre Surface. // Textile Research Journal. 77, 12(2007), pp. 914-922.

[4] Bankvall, C. Heat Transfer in Fibrous Material. // Journal of Testing and Evaluation. 1, 3(1973), pp. 235-243.

[5] Bomberg, M.; Klarsfeld, S. Semi-Empirical Model of Heat Transfer in Dry Mineral Fibre Insulations. // Journal of Thermal Insulation. 6, 1(1983), pp. 157-173.

[6] Dudzik, S. A simple method for defect area detection using active thermography. // Opto-Electronics Review. 17, 4(2009), pp. 338-344.

[7] Novaković, D.; Kašiković, N.; Zeljković, Ž.; Agić, D.; Gojo, M. Thermo graphic analysis of thermal effects on the change of colour differences on the digitally printed textile materials. // Tekstil. 59, 7(2010), pp. 297-306. 
[8] Rogalski, A. Infrared Detectors, Gordon and Breach Science Publishers, Amsterdam, 2000.

[9] Dudzik, S. Termolab - a digital measurement system for the thermal image processing, uses a universal matrix interface. // Proc. 35 ${ }^{\text {th }}$ Inter. University Conf. of Metrologists MKM'03, Cracow, 2003, pp. 95-98 (in Polish).

[10] Yang, Y.; Naaranib, V. Effect of steaming conditions on colour and consistency of ink-jet printed cotton using reactive dyes. // Coloration Technology. 120, 3(2004), pp. 127-131.

[11] Minkina, W.; Dudzik, S. Simulation analysis of uncertainty of infrared camera measurement and processing path. // Measurement. 39(2006), pp. 758-763.

[12] Zhang, C.; Fang, K. Surface modification of polyester fabrics for inkjet printing with atmospheric-pressure air/ $\mathrm{Ar}$ plasma. // Surface and Coatings Technology. 203, 14(2009), pp. 2058-2063.

[13] Kašiković, N. Razvoj modela praćenja procesnih parametara štampe tekstilnih materijala, $\mathrm{PhD}$ Thesis, Faculty of technical sciences, Novi Sad, Serbia, 2012.

[14] Gulrajani, M. L. et al. Colour measurement principles, advances and industrial applications, Woodhead Publishing Limited in association with The Textile Institute Abington Hall, Granta Park, Great Abington Cambridge CB21 6AH, UK, 2010

[15] Kašiković, N.; Novaković, D.; Karlović, I.; Vladić, G. Influence of ink layers on the quality of ink jet printed textile materials. // Tekstil ve konfeksiyon. 22, 2(2012), pp. 115-124.

[16] Pallant, J. SPSS Survival Manual, Allen \& Unwin, Crows Nest NSW 2065, Australia, 2011.

\section{Authors' addresses}

Nemanja Kašiković, PhD

University of Novi Sad

Faculty of technical sciences

Trg Dositeja Obradovića 6

21000 Novi Sad, Serbia

Phone: +381214852622

E-maile: knemanja@uns.ac.rs

Dragoljub Novaković, PhD

University of Novi Sad

Faculty of technical sciences

Trg Dositeja Obradovića 6

21000 Novi Sad, Serbia

Phone: +381214852620

E-maile: novakd@uns.ac.rs

Neda Milić, MSc

University of Novi Sad

Faculty of technical sciences

Trg Dositeja Obradovića 6

21000 Novi Sad, Serbia

Phone: +381214852625

E-maile: milicn@uns.ac.rs

Gojko Vladić, MSc

University of Novi Sad

Faculty of technical sciences

Trg Dositeja Obradovića 6

21000 Novi Sad, Serbia

Phone: +381214852622

E-maile: vladicg@uns.ac.rs

Željko Zeljković, $M r$

University of Novi Sad

Faculty of technical sciences

Trg Dositeja Obradovića 6

21000 Novi Sad, Serbia

Phone: +381214852627

E-maile: zeljkoz@uns.ac.rs

Mladen Stančić, MSc

University of Banja Luka

Faculty of technology

Vojvode Stepe Stepanovića 73

78000 Banja Luka, Bosnia and Herzegovina

Phone: +38751434357

E-maile: mladen.stancic@tfbl.org 